\title{
The Meaning of Breast Cancer Patients' Experience In Hospital X: a Viewpoint From Patient Centered Care
}

\author{
Farida Rozany,* Indah Winarni, ** Viera Wardhani**** \\ *M Author Correspondence: farida.rozany@gmail.com \\ * Master of Hospital Management, Medicine Faculty, Universitas Brawijaya, Malang, East Java, Indonesia \\ **Master of Hospital Management, Medicine Faculty, Universitas Brawijaya, Malang, East Java, Indonesia \\ ***Master of Hospital Management, Medicine Faculty, Universitas Brawijaya, Malang, East Java, Indonesia
}

\begin{tabular}{l}
\hline I N D E X I N G \\
\hline Keywords: \\
Patient Experience; \\
Patient Centered Care; \\
Qualitative;
\end{tabular}

Kata kunci:

Pengalaman pasien;

Patient centered care;

Kualitatif; \begin{abstract}
A B S T R AC T
Patient experience is a significant factor in improving hospital service quality. This study aims to determine the meaning of treatment received by breast cancer patients during the treatment period. In the treatment of breast cancer, the patients require a personalized service or patient centered care. This research is a qualitative analysis with phenomenology approach. Informants in this study were breast cancer patients who underwent chemotherapy treatment and had mastectomy. Data were obtained through in-depth interviews in patients with breast cancer. The results of the study revealed there are 10 themes, namely worrying about something uncomfortable in the body, resigning to the doctor's recommendations, feeling comfortable and uncomfortable in the service received, feeling stress after recognizing the disease suffered, feeling fearful to the disease, experiencing pain before and after treatment, obtaining encouragement, refraining from thinking that slows down the healing, feeling of having no choice over the disease, and feeling of not obtaining explanation. There is relevance between theme and patient centered care.
\end{abstract}

\begin{abstract}
Pengalaman pasien merupakan hal yang penting untuk dinilai untuk meningkatkan kualitas pelayanan di rumah sakit. Penelitian ini bertujuan untuk mengetahui makna perawatan yang diterima oleh pasien kanker payudara dalam masa perawatan. Dalam perawatan pasien kanker payudara dibutuhkan pelayanan secara personal atau patient centered care. Penelitian ini menggunakan pendekatan kualitatif dengan pendekatan fenomenologi. Informan pada penelitian ini adalah pasien kanker payudara yang menjalani pengobatan kemoterapi dan telah dilakukan operasi pengangkatan payudara. Data diperoleh melalui wawancara mendalam pada pasien penderita kanker payudara. Hasil penelitian ada 10 tema, mengkhawatirkan adanya sesuatu yang tidak nyaman di tubuhnya, pasrah kepada rekomendasi dokter, merasa nyaman dan tidak nyaman dalam pelayanan yang diterima, stres saat mengetahui penyakit yang diderita, mengalami sakit sebelum dan sesudah penanganan, perasaan takut pada penyakit kanker yang diderita, merasa tidak punya pilihan terhadap sakit yang diderita, mendapat dukungan semangat, menahan diri dari berpikir yang memperlambat kesembuhan, dan merasa tidak mendapat penjelasan. Terdapat relevansi antara tema dengan patient centered care.
\end{abstract}

(C) 2019 JMMR. All rights reserved

Article history: received 5 Feb 2017; revised 15 Sept 2017; accepted 25 Okt 2017

\section{INTRODUCTION}

Patient centered care (PCC) is a health care concept that is consistent with the values, needs, and wishes of patients. The concept of PCC literally means that patients are actively involved in their treatment. Stated that to achieve effective PCC goals, physicians have to be able to identify the approaches that are proper to the needs of their patients. ${ }^{-}$The three core elements of the approach are communication, cooperation, and health promotion.

The results obtained are increased patient satisfaction, good communication among officers and patients and also their families, and improved patient health status. As healthcare reform continues to drive hospitals to achieve better outcomes with fewer resources at a lower cost, patient-centered care will continue to take on greater importance. Evidence shows that patientcentered care improves outcomes by reducing length of stay, readmissions, and emergency department visits and enhances patient compliance with plans of care. ${ }^{2}$

Communication is one of the problems in implementing PCC in hospitals..$^{1}$ Data show that communication that is one of the important elements of PCC is still being criticized by patients. Data about complaints in the first and second quarters of 2016 showed 
that $90 \%$ of complaints were related to ineffective communication with patients. ${ }^{-}$these data indicate that PCC has not been fully implemented in Hospital X. The patients want to be involved in the treatment, listened to everything felt, and given information and education related to their illness. ${ }^{4}$

The results of interviews with the informants revealed that they did not get clear information about the chemotherapy they were going to undergo. An effective communication of healthcare information from the clinician to the patient, but also included approaches to effective patient information uptake by the clinician. Effective information uptake was seen as being an essential step in tailoring information to suit patient needs, vulnerabilities, and capacities. ${ }^{1}$

Physical comfort was also not fulfilled optimally. This was indicated by the informants who still felt the pain when undergoing chemotherapy. Revealed that several factors involved in obtaining patient comfort during the treatment period are the physical experience about the illness, the experience of suffering from illness, customer service, and the promptness of officers' response in performing services. $\underline{5}$

This research focuses on uncovering the meaning of breast cancer patient experience while undergoing inpatient care at Hospital $\mathrm{X}$ from the perspective of patient centered care. Breast cancers patients require complex treatment, not only do they require biomedical support, but also psychosocial and emotional as well as involving multidisciplinary health professions..$^{-}$The experience explored included the meaning of the experience of breast cancer patients in experiencing the symptoms of the disease, receiving doctor's recommendations, recognizing the disease, undergoing the disease, and receiving encouragement when undergoing the illness.

\section{RESEARCH METHOD}

This research is qualitative research with a phenomenological approach. Data collection was done using in-depth interviews in April - June 2017. The informants in this study were breast cancer patients who had mastectomy on the left breast and underwent the first serial of chemotherapy.

The equipment used in this study was a recorder and a question list or an interview guide.

Data analysis was performed using interpretive phenomenology analysis (IPA). At the interview, the researchers had analyzed the answers interviewed. Following this, editing was done, and the results were grouped according to the research problem. Qualitative descriptive data analysis was performed in the form of narration.

\section{RESULT AND DISCUSSION}

This study resulted in ten themes based on the thematic analysis of interpretive phenomenology analysis. The ten themes generated in this study illustrate the experience of the inpatients about the implementation of patient centered care at Hospital X.

\section{Worrying about something uncomfortable in the body}

The informant (SF) showed anxiety about the presence of a foreign object in her body, thus making the informant compelled to get treatment.

" At first, it is like dull pain before the menstruation, I noticed there was a lump when I took a bath, but it's just on the left, when I pressed it above the nipple here, it moved there and there, then I told my friend about my dull pain in my breast, she said not to worry because it is normal, I have waited until one week, but it still hurts." (SF1.2.12)

The physician responded to this condition by referring to have an anatomic pathology laboratory examination.

Studies showed women with the presence of dense tissues in their breast have four to five times the chance of getting cancer than those without dense tissues. ${ }^{?}$

The first patient centered care dimension is respecting the values, choices, and needs that focus on the patient. ${ }^{-}$If health personnel listen to the patient's needs and prepare an appropriate treatment plan for the patient, it will increase patient satisfaction and healing process. ${ }^{-}$

\section{Resigning to doctor's recommendations}

The informant showed resignation by obeying the doctor's advice to undergo chemotherapy treatment, even though she had not received information about it.

"... no explanation, Miss, I was only given a schedule for inpatient care for chemotherapy, my turn was number 60 , so the doctor was sleepy, I wanted to ask but I was reluctant ... I was examined at 2 in the morning, thus I felt so hesitant to ask, the doctor seems to be sleepy." (SF2.6.82)

Patient compliance with physician recommendations is influenced by perception equality between the patient and the doctor. This perception equality can be obtained if the physician provides detailed information, so the best joint decision is reached for the patient. ${ }^{10}$ Based on the PCC 
dimensions on information, communication, and education, the provision of clear information and education by physicians to patients will have an impact on the emergence of empathy from doctors and the trust from patients.

\section{Feeling comfortable and uncomfortable in the service received during the treatment period}

The informant felt painful while undergoing chemotherapy treatment.

"when medicine entered, especially when the nurse set a quick drip, my stomach would get squeezed, my head would hurt, my body was stiff, my sighting was also dark, that was the way I feel." (SF2.6.98)

This theme correlates to the PCC dimension of physical and environmental comfort. During the treatment period, the provider must be able to overcome this pain. One of the ways is the intervention technique, or coaching, that is inviting conversation and actively listening to every patient's complaint. Assistance to the patients will also have an impact on reducing their anxiety level. ${ }^{11}$ Comfort in the treatment period will affect the patient's recovery, and is supported by giving attention, empathy from officers, reliability, and responsiveness of the health personnel in conducting handling. .12

The first informant expected that the drugs were carried out through the infusion flow slowly and the nurse provided assistance during therapy. The presence of the nurse beside the informant made the pain not felt.

"Basically, if the second medicine enters, I always feel painful, but I forgot what sequence the chemo was ... once I was accompanied by a male nurse ... I was invited to chat and I didn't feel that the medicine was finished after an hour and a half, I didn't feel the pain."(SF2.6.100)

Nurses are one of the health personnel who conduct a lot of contact with patients, so it is expected that their presence in providing information and education to patients can reduce the level of anxiety. ${ }^{11}$

\section{Feeling stress after recognizing the disease suffered}

The first informant reported that she was depressed when she found out the breast cancer diagnosis from the doctor.

"I was sad and shocked ..." (SF2.6.48)

"I cried immediately, Miss" (SF2.6.54)

The informant's feeling of sadness is a normal form. Building relationships with patients and families contributes to understanding what problems the patient is most concerned with and how their illness or injury has affected their life. ${ }^{-1}$ The stress felt by sufferers will worsen if they do not have good spiritual capacities so that it will make patients worse in deep suffering. This requires social and spiritual supports in patients with breast cancer. ${ }^{13}$

Cancer patients in their treatment need to be accompanied by psychological and social support scheme so that patients can have optimism and adapt to live healthy again. ${ }^{-}$

\section{Feeling fearful to the disease}

The informant felt that she does not have enough good deeds when she faces death. The informant also felt fear that the disease that had infected her body would lead her to death like her neighbors.

"I don't have enough preparation to die ..." (SF2.6.58)

"There were two of my neighbors around my house who were sick like that, it was going on until the wound was given a bandage and smelly, shortly they died, that is what I'm afraid of ..." (SF2.6.56)

One of fear felt is that she was already on the verge of death, so this feeling requires emotional support and good communication. Breast cancer patients will feel close to death. This fear is felt mostly by female patients. ${ }^{-14}$

Nurses must be able to establish good communication with patients. Through communication, the patient would be better able to convey her feelings, thus reducing the level of anxiety when a medical action will be taken..$^{15}$

\section{Experiencing pain after treatment}

The informant felt weak and useless after undergoing chemotherapy treatment.

"after the chemotherapy I became useless, for ten days I could not do anything, I will feel nauseous if eating and can eat after four days, I told my neighbors that I would do chemotherapy again and would be useless again." (SF2 .6.90)

Several ways that can be taken and make patients feel comfortable to undergo chemotherapy treatment are by giving detailed explanations about the process, the side effects caused, and the ways to overcome. Establishing good communication with patients about what is felt during undergoing chemotherapy becomes important since it allows the health personnel to know the response of the patient's body to chemotherapy treatment; and also, by asking the patient to write down the benefits obtained from chemotherapy treatment. Some of these methods are 
expected to reduce the pessimism of patients who undergo chemotherapy treatment. $\frac{16}{}$

\section{Obtaining encouragement}

The informant felt that the supports from doctors and fellow patients were important.

"The doctor told not to follow what people say. Ma'am, even though you will lose one breast and people will talk about this and that, just ignore it. Calm your mind. Later, you will get better, you can work again. I become enthusiastic, and my heart settled down."

Providing compassionate and empowering care was cited as a component of achieving effective communication and contributing to the development of a strong clinicianpatient relationship based upon patient feelings of autonomy and trust. ${ }^{-}$

In their treatment plan, cancer patients need to be accompanied by plans on the provision of psychological and social support. This is in accordance with the dimensions of emotional support and avoiding fear and anxiety. ${ }^{4}$

\section{Refraining from thinking that slows down the healing}

The informant expressed her gratitude about the smooth operation undertaken.

"Thank God the surgery went well, I didn't feel pain during the surgery, people said that the surgery is painful, thank God I did not feel that, Miss" (SF2.6.78)

Good spiritual capacity is associated with a good emotional state. Spiritual service is one of the patient's needs, especially among breast cancer patients. The existence of a strong spiritual basis in the patients will impact her emotional state..$^{17}$ A more systematic and integrated approach to inclusion of spirituality in patient care may enhance patient and family satisfaction. ${ }^{18}$

Baldacchino and Nurlaila in Lutfa revealed that motivational supports provided by nurses and families to patients aid the patient recovery. $\frac{11}{}$ This support can be given by encouraging patients to take the therapies. Nurses and families must also convince the patients that conditions can improve, and there is a wisdom that can be taken from these conditions.

\section{Feeling of having no choice over the disease}

The informant felt that choosing chemotherapy treatment was something difficult for her, but because of the willingness to recover she still chose chemotherapy.
"But what can I do, if I don't get chemo, it won't recover, Miss." (SF2.6.90)

In choosing the treatment, chemotherapy is a difficult option for the patient because the treatment does not offer any guarantee about the patient's recovery. However, the patients eventually continue to choose chemotherapy treatment because it aims to prevent the spread of cancer from happening and to prolong the possibility of survival. ${ }^{19}$ Strategies on how to be sensitive to patient needs included acknowledging and adapting to unique patient identifiers. For example, clinicians are urged to observe and reflect on fluctuating levels of patient alertness, patient comfort levels in the presence or absence of family members, and different communication barriers such as hearing loss, in order to facilitate clinical interactions. ${ }^{-}$Health care providers must be able to provide a proper response to what is desired, expected, and needed by patients. $\stackrel{20}{.}$

\section{Feeling of not obtaining explanation}

The informant revealed the information before the chemotherapy treatment.

"... no explanation, Miss, I was only given a schedule for inpatient care for chemotherapy, my turn was number 60 , so the doctor was sleepy, I wanted to ask but I was reluctant ... I was examined at 2 in the morning, thus I felt so hesitant to ask, the doctor seems to be sleepy." (SF2.6.82)

Besides requiring emotional support, chemotherapy patients also need information about the disease and treatment that will be undertaken. ${ }^{21}$

The needs for information are influenced by the level of education. The higher the level of education, the more complex the information is needed about the disease. The information provided in detail can reduce the level of anxiety about the procedure performed. $\frac{22}{}$ Fatigue experienced by doctors can reduce empathy and inhibit the provision of information. $\frac{20}{}$

Picture 1 explains correlation between dimensions of patient centered care and the theme of the study. From eight dimensions of patient centered care, there are three dimensions related to the theme of the study, namely emotional support, information and education, and physical comfort and from three dimensions have related to the ten themes in the study. 

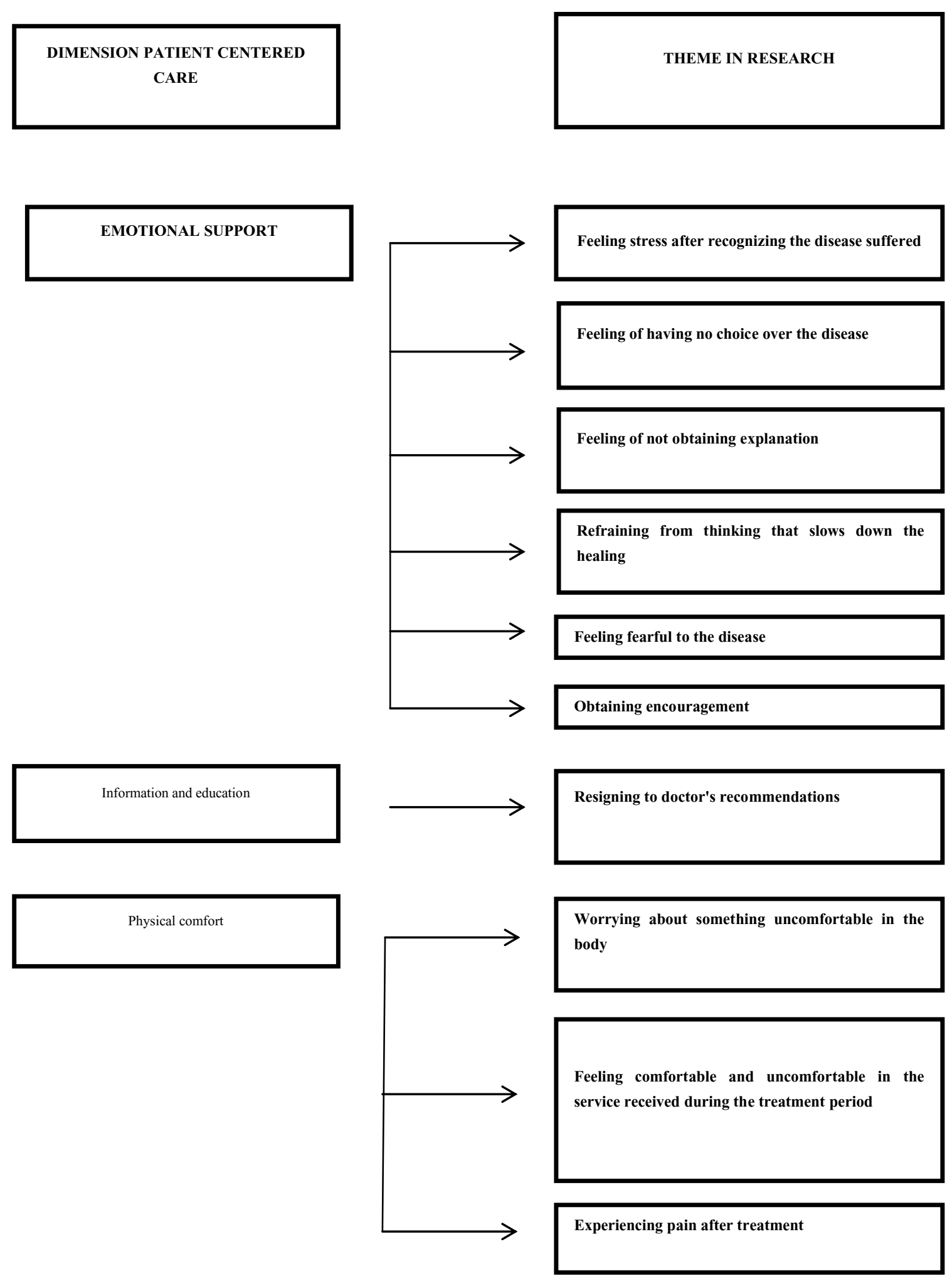

Picture 1. Correlation between dimension of patient centered care and theme in study 


\section{CONCLUSION}

This study identifies ten themes that illustrate the meaning of the patient's experience while undergoing inpatient care at Hospital X viewed from a patient centered care perspective. All of the ten themes show a relationship to the patient centered care (PCC) dimensions. Based on the relationship between the themes and the PCC dimension, the dimensions most frequently revealed by informants are emotional support and avoidance of fear and anxiety, information, communication, and education; and physical and environmental comfort. Based on the responses made by the health personnel from the informant's expression, there is a dimension that was responded positively, namely emotional support and avoiding fear and anxiety; and respecting the values, preferences, and needs that were focused to the patients. Several dimensions that obtained positive and negative responses are physical and environmental comfort and information, communication, and education. From the relationship between the themes and the dimensions of PCC, several elements of PCC that have not been optimally implemented are integrated services, communication between health workers and patients. Whereas, the dimensions that have not been revealed are service coordination and family involvement in decision making.

Based on the study of these ten themes, it is necessary to develop a service system that provides holistic care to patients by considering the biological, psychosocial, and spiritual aspects because these three aspects can support the recovery of patients when obtaining the hospital care. Hospitals need to ensure physical comfort of patients, especially for patients who experience pain during chemotherapy treatment by conducting multidisciplinary pain management and alternative intervention methods such as playing music and coaching. Hospitals can facilitate the information and education needs of patients by providing trained facilitators who act as communicators, educators, as well as counselors for patients in need. The informants used in this study were inpatients suffering from breast cancer and undergoing chemotherapy. This research did not include all patients with complex breast cancer diagnoses and extensive treatment periods, such as patients who have cancer spread to other organs, because this can affect the emergence of the identified themes. Further studies need to focus on the experience of patients with breast cancer who need more complex services and longer treatment time at the hospital.

\section{REFERENCE}

1. Constand, M. K. Scoping review of patient-centered care approaches in healthcare. BMC Health Services Research, (2014): 14, 271.

2. Cliff, Barbara, RN,PhD., F.A.C.H.E. The Evolution Of Patient-Centered Care. Journal of Healthcare Management, (2012): 57(2), 86-8.

3. Humas. Laporan Komplain Pasien RS X. (2016).

4. Balogh, E. P. Patient-Centered Cancer Treatment Planning: Improving the Quality of Oncology Care. Summary of an Institute of Medicine Workshop. The Oncologist, (2011):16, 1800 -1805.

5. Wolf, J. A. Defining Patient Experience. Patient Experience Journal, (2014): 1.

6. Levit, L. Delivering High-Quality Cancer Care: Charting a New Course for a System in Crisis, Washington, National Academies Press. (2013).

7. Manning, M. A. Knowledge of breast density and awareness of related breast cancer risk. Journal of Cancer Education, (2013): 28, 270-4.

8. Australian Commision on Health Care (ACHC). Patient Centred Care: Improving Quality and Safety by Focusing Care on Patients And Consumers. (2010).

9. Street, R. L. Patient preferences and healthcare outcomes: an ecological perspective. Pharmacoeconomics and Outcome Research, (2012): 12, 167-180.

10. Umar, N. Outcomes associated with matching patients' treatment preferences to physicians' recommendations: Study methodology. BMC Health Services Research, (2012): 12.

11. Lutfa, U. Faktor-Faktor Yang Mempengaruhi Kecemasan Pasien Dalam Tindakan Kemoterapi di RS dr. Moewardi Surakarta Berita Ilmu Keperawatan. (2017). 1, 187-192

12. Naidu, A. Factors affecting patient satisfaction and healthcare quality. International Journal of Health Care Quality Assurance, (2009): 22,366-381.

13. Mirmohamedi, S. J. Evaluation of the Return to Work and It's Duration After Myocardial Infarction. ARYA Atheroscleroris, (2014): 10, 137-140.

14. Ha, J. F. Doctor-Patient Communication: A Review. Springer International Publishing Switzerland, (2010).1.

15. Kasana, N. Hubungan Komunikasi Terapeutik Dengan Tingkat Kecemasan Pasien Pre Operasi SC di RSUD Karanganyar. In: SURAKARTA, S. K. H. (ed.). Surakarta. (2014). 
16. Harrington Jr, Joseph E. "Optimal corporate leniency programs." The Journal of Industrial Economics 56.2 (2008): 215-246.

17. Visse, A. Spirituality and well-being in cancer patients: a review. Psycho-Oncology, (2010): 19.

18. Suzette Brémault-Phillips et al. Integrating Spirituality as a Key Component of Patient Care. Religions. (2015). 476-498

19. Chan, K. Aggressiveness of cancer-care in lung cancer patients near the end-of-life in an oncology center in Hong Kong. Journal of Pain Management, 5. (2012): 71-82.

20. Torres, O. Y. Association between sick leave prescribing practices and physician burnout and empathy. PLoS One, (2015): 10.

21. Perocchia, Rosemarie Slevin, et al. "Patient-centered communication in cancer care: the role of the NCI's Cancer Information Service." Journal of Cancer Education 26.1 (2011): 36-43.

22. Husson, O. The relation between information provision and health-related quality of life, anxiety and depression among cancer survivors: a systematic review. Annals of Oncology, 22 (2011): 761-772. 